\title{
Problematika Hibah Warisan Ditinjau Dari Aspek Keadilan Studi di Pengadilan Negeri Tobelo
}

\section{Inherintance Grant Prloblematics Reviewed From The Aspect of Justice Study in Tobelo District Court}

\author{
Reli Jevon Laike ${ }^{1 *}$, David Laike ${ }^{2}$ \\ 1)Prodi Hukum, Fakultas Ilmu Sosial Dan Kependidikan, Universitas Hein Namotemo, \\ Indonesia \\ 2) Fakultas Hukum, Universitas Kristen Satya Wacana, Indonesia \\ *E-mail: Rely.laike@gmail.com
}

\begin{abstract}
Abstrak
Tulisan ini berdasarkan fakta yang digali melalui putusan pengadilan di Pengadilan Negeri Tobelo dalam perkara perdata khususnya hibah warisan oleh pewaris kepada alih warisnya. Persoalan inti yang dikajinya adalah apakah pemberian hibah warisan oleh pewaris kepada salah satu alih warisnya sudah mencerminkan keadilan. Berdasarkan persoalan tersebut metode yang digunakan dalam penulisan ini adalah jenis penelitian hukum normatif yang fokusnya pada putusan Pengadilan Negeri Tobelo sebagaimana dalam perkara waris. Merujuk pada hasil pembahasan yang telah diuraikan pada bab-bab sebelumnya, maka dibagian penutup ini penulis dapat mengambil kesimpulan yakni, dalam perkara ini seyogyanya hakim tidak terikat pada undang-undang saja dalam hal ini pertimbangan sahnya suatu pemberian hibah warisan oleh pewaris kepada ahli warisnya.
\end{abstract}

Kata Kunci: Keadilan, Hibah Warisan, Putusan Pengadilan.

\begin{abstract}
This paper is based on facts excavated through a court ruling in the Tobelo District Court in a civil lawsuit in particular an inheritance grant by the heir to the heirs. The core issue it asks is whether a legacy grant granting by the heir to one of its heirs already reflects justice. Based on the issue the method used in this writing is a normative type of legal study which focused on the decision of the Tobelo District Court as in the case of inheritance. Referring to the results of the discussions that have been outlined in the preceding chapters, then the concluding section of this author can take the conclusion that, in this case the judge is not bound to the law alone in this case the consideration of a grant of inheritance by heir to the heirs.
\end{abstract}

Keywords: justice, inheritance grants, court judgments.

Cara citasi : Laike, Reli Jevon. \& Laike, David. (2020). Problematika Hibah Warisan Ditinjau Dari Aspek Keadilan Studi Di Pengadilan Negeri Tobelo. Jurnal Intervensi Sosial dan Pembangunan (JISP) Vol 1 No 2 September 2020, 107-118. 
Laike, Reli Jevon. \& Laike, David. Problematika Hiba Warisan Ditinjau Dari Aspek Keadilan Studi Di Pengadilan Negeri Tobelo

\section{PENDAHULUAN}

Sengketa, konflik, perselisihan, atau pelanggran adalah hal yang bisa saja terjadi. Sengketa inipun berfariasi baik secara individu dengan idividu, maupun kelompok atau badan hukum bahkan negara dan wargapun tidak jarang bersengketa. Dalam menghadapi konflik kepentingan manusia ini terjadi oleh seni yang berupaya penyelesaian pereselisihan, sengketa atau konflik yang disebut peradilan. Yang dimaksud dengan peradilan pada dasarnya ialah pelaksanaan hukum, dalam hal konkret adanya tuntutan hak atau terjadinya sengketa atau pelanggaran, yang fungsinya dijalankan oleh suatu badan yang berdiri sendiri dan bebas dari pengaruh apa atau siapapun dengan cara memberikan putusan yang bersifat mengikat dan bertujuan mencegah aksi sepihak.

Pengadilan adalah sebuah lembaga negara yang oleh Undang-Undang Dasar Negara Republik Indonesi Tahun 1945 merupakan lembaga yudikatif yang merdeka dan independen dengan tugas dan fungsi diatur secara mandiri dan terpisa dari lembagalembaga lain. Bahwa pengadilan juga merupakan tempat untuk mencari keadilan bagi para pencari keadilan. Lalau pertanyaan kemudian apakah melalui lembaga pengadilan keadilan bisa tercapai bagi para pihak ? sesungguhnya masalah keadilan adalah sebuah tema yang selalu menjadi soroti dalam kehidupan manusia.

Keadilan dalam kehidupun seharai-hari identik dengan kebutuhan akan makanan dan minuman yang mana selalu dibutuhkan setiap insan manusia. Dalam sosial yang paling kecil juga dalam hal ini keluargapun sangat memerlukan sebuah keadilan misalnya antara sesama anak, anak dengan orang tua dan orang tua dengan anak. Dalam berperkara di pengadilan, bagi pihak-pihak keadilan merupakan dambaan bersama yang kemudian dirumuskan dalam sebuah putusan hakim. Namun ada begitu banyak pihakpihak yang tidak menerima sebuah putusan hakim karena dirasakan tidak adil.

Keadilan dalam hukum waris apabila hal itu diwujudkan dalam pembagian warisan oleh pewaris. Terkadang dalam kehidupan sehari-hari untuk menghindari terjadi konflik antara sesama ahli waris, pewaris semasa hidupnya telah mengatur pembagian warisan terhadap para ahli warisnya. Hal ini secara tidak langsung mau memberikan keadilan terhadap sesama para ahli waris. Harta yang kemudian diberkian oleh pewaris dalam bentuk wasiat atau hibah. Hibah menurut KUHPerdata Pasal 1666 menyatakan bahwa, suatu persetujuan dengan mana si penghibah diwaktu hidupnya dengan cumacuma dan dengan tidak dapat ditarik kembali, menyerahkan sesuatu benda guna keperluan si penerima hibah yang menerima penyerahan itu. Perluh ditegaskan disini 
bahwa penghibahan termasuk perjanjian sepihak, dimana hanya satu pihak saja yang mempunyai kewajiban atas perjanjian ini, yaitu si penghibah, sedangkan pihak yang menerima hibah sama sekali tidak mempunyai kewajiban.

Prinsipnya benda yang sudah dihibahkan tidak dapat ditarik kembali menjadi hak milik pemberi hibah. Akan tetapi, untuk kepentingan kewarisan, benda yang telah dihibahkan dapat "diperhitungkan kembali" nilainya ke dalam total harta peninggalan seolah-olah belum dihibahkan (Pasal 916a sampai Pasal 929 KUHPerdata). Berdasarkan hal tersebut, dalam penulisan ini menjadi titik untuma pembahasan peneliti adalah putusan hakim dalam perkara hibah warisan. Yaitu putusan Nomor: $175 \mathrm{~K} / \mathrm{Pdt} . / 2014$. Singkatnya kedudukan perkara ini adalah sengketa mengenai surat hibah warisan. Pihak yang berperkara adalah merupakan parah ahli waris. Yang dipermasalahkan adalah parah ahli waris berjumlah empat orang, dan yang menerima hiba atas satu objek bidang tanah (harta warisan) hanyalah satu orang ahli waris. Hal inilah yang kemudian bagi para ahli waris yang lain merasa tidak mendapatkan hak yang setara dengan seorang ahli warislainnya. Menariknya putusan hakim menerima dan mengabulkan bahwa pemberian hibah kepada seorang ahli waris adalah sah dan mengikat. Berdasarkan latar belakang masalah tersebut, dapat dirumuskan permasalahan dalam penulisan ini adalah apakah putusan hakim dalam perkara putusan Nomor: 175 K/Pdt./2014. tentang surat hibah warisan telah memenuhi rasa keadilan?

\section{METODE PENELITIAN}

Jenis penelitian hukum yang digunakan adalah jenis penelitian hukum normatif. Penelitian ini merupakan usaha untuk menemukan apakah hukum yang diterapkan telah memenuhi rasa keadilan dalam menyelesaikan perkara putusan Nomor: 175 K/Pdt./2014. Penelitian normatif ini memerlukan sumber data sekunder sebagai sumber data utama dan data primer sebagai penunjang.

\section{HASIL DAN PEMBAHASAN}

\section{Konsep Keadilan}

Aristoteles adalah filsuf Yunani yang agak jelas berbicara mengenai keadilan. Bagi Aristoteles keutamaan, yaitu ketaatan terhadap hukum (hukum polis pada waktu itu, tertulis atau tidak tertulis) adalah keadilan. Dengan kata lain keadilan adalah keutamaan dan ini bersifat umum. Aristoteles juga membedakan keadilan ke dalam dua bagian yaitu 
Laike, Reli Jevon. \& Laike, David. Problematika Hiba Warisan Ditinjau Dari Aspek Keadilan Studi Di Pengadilan Negeri Tobelo

keadilan distributif dan keadilan komutatif. Keadilan distributif adalah merupakan tugas pemerintah terhadap warganya, menentukan apa yang dapat dituntut. Keadilan distributif ini merupakan kewajiban pembuat undang-undang untuk diperhatikan dalam menyusun undang-undang. Disini bukan kesamaan yang dituntut tetapi perimbangan. Keadilan komutatif memberi kepada setiap orang sama banyaknya. Dalam pergaulan di dalam masyarakat, keadilan komutatif merupakan kewajiban setiap orang terhadap sesamanya. Di sini yang dituntut adalah kesamaan. Yang adil ialah apabila setiap orang diperlakukan sama tanpa memandang kedudukan dan sebagainya.

Aristoteles menyatakan bahwa ukuran keadilan adalah bahwa :

1. Seseorang tidak melanggar hukum yang berlaku, sehingga keadilan berarti "lawful", yaitu hukum tidak boleh dilanggar dan aturan hukum harus diikuti; dan

2. Seseorang tidak boleh mengambil lebih dari haknya, sehingga keadilan berarti persamaan hak (equal).

Aristoteles mengatakan pula, bahwa kata adil mengandung lebih dari satu arti. Adil dapat berarti menurut hukum, dan apa yang sebanding, yaitu yang semestinya. Disini ditunjukan, bahwa seseorang dikatan berlaku tidak adil apa bila orang itu mengambil lebih dari bagian yang semestinya. Orang yang tidak menghiraukan hukum juga tidak adil, karena semua hal yang didasarkan pada hukum dapat di anggap sebagai adil. Aristoteles menjelaskan perluhnya diselidiki perbuatan-perbuatan mana keadilan itu berhubungan dan di tengah perbuatan-perbuatan mana keadilan itu berada. Keadilan adalah sikap bertindak yang ingin bertindak adil, yang tidak adil adalah orang yang melanggar undang-undang yang dengan tidak sepantasnya menghendaki lebih banyak keuntungan dari orang lain. Di antara kedua kepentingan yang tidak sama, hukum itu harus berdiri sama tengah, sebab barang siapa yang berbuat tidak adil, mengambil terlalu banyak barang dan barang siapa yang menderita ketidakadilan dari orang yang berbuat tidak adil tadi dengan memperbaiki imbangan dengan hukuman. Sebab pergi kepada hakim berarti pergi kepada keadilan yang hidup. Maka untuk bertindak secara adil, kata Aristoteles, seorang hakim harus menyelami sungguh-sungguh perkara-perkara yang konkret, seolah-olah hakimlah sebagai saksi mata sendiri. 


\section{Putusan Hakim}

Putusan hakim yang disebut juga putusan pengadilan, merupakan suatu hal yang ditunggu-tunggu parah pihak yang berperkara. Putusan hakim ini diharapkan dapat mengakhiri perkara dan pihak-pihak yang berperkara dapat memperoleh kepastian hukum dan keadilan. Agar putusan hakim benar-benar memenuhi kepastian hukum dan keadilan, hakim di harapkan untuk mengetahui secara cermat apa yang menjadi duduk perkara dan yang terpenting juga mengetahui peraturan hukum yang terkait dengan perkara yang sedang diperiksa. Terkait hal tersebut, untuk memperdalam pengetahuan tentang putusan hakim maka penulis akan mengemukakan pengertian putusan hakim menurut beberapa ahli. Menurut Sudikno Mertokusumo, putusan hakim adalah putusan yang oleh hakim, sebagai pejabat negara yang diberi wewenang untuk itu, diucapkan di persidangan dan bertujuan untuk mengakhiri suatu sengketa antara para pihak. Senada dengan hal tersebut menurut Ridwan Syahrani, putusan hakim adalah suatu pernyataan hakim yang diucapkan pada sidang pengadilan yang terbuka untuk umum untuk menyelesaikan dan mengakhiri suatu perkara perdata. Mahkamah Agung telah menentukan pilihan agar hakim dalam membuat putusan berpedoman tiga hal:

1. Unsur yuridis, yang merupakan unsur pertama dan utama.

2. Unsur filosofis, berintikan kebenaran dan keadilan.

3. Unsur sosiologis, yang mempertimbangkan tata nilai budaya yang hidup dan berkembang dalam masyarakat.

\section{Hibah Warisan Menurut KUHPerdata}

Sebelum penulis membahas lebih dalam mengenai hibah warisan menurut KUHPerdata, pertama-tama penulis uraikan apa yang dinamakan dengan hukum waris. Berbicara mengenai hibah warisan tentu berkaitan erat dengan hukum waris. Bahwa Saat ini pengaturan hukum waris (yang merupakan bagian dari hukum perdata) di Indonesia masih bersifat dualism dan pluralisme. Hal demikian tidak terlepas dari sejarah hukum berlakunya hukum perdata di Indonesia. Sebelum Indonesia merdeka, sebagai akibat penjajahan colonial Belanda, politik hukum pemerintah Hindia Belanda pada waktu itu yang dituangkan dalam Pasal 131 dan 163 Indische Staatregeling (IS), terdapat penggolongan hukum dan penggolongan penduduk.

Mengacu pada ketentruan tersebut berlakulah Hukum Perdata Eropa (Burgerlijk Wetboek) yang diberlakukan di Indonesia berdasarkan Staatblad No.23/1847 Bagi Golongan Erapa, Hukum Adat bagi Golongan Bumiputra (penduduk Indonesia Asli) dan 
Laike, Reli Jevon. \& Laike, David. Problematika Hiba Warisan Ditinjau Dari Aspek Keadilan Studi Di Pengadilan Negeri Tobelo

Hukum Adat masing-masing bagi Golongan Timur Asing. Dalam perjalanannya KUHPerdata di berlakukan bagi golongan Timur Asing dan diberikan kemungkinan bagi Golongan Bumiputra untuk melakukan penundukan diri secara sukarela (gelijkstelling) terhadap KUHPerdata dan Hukum Adat, didalamnya termasuk hukum kewarisannya. Selanjutnya dalam perkembangan agama Islam, didaerah tertentu berlakukah hukum Islam, khususnya yang dipergunakan dalam pembagian waris. Dengan demikian ada pluralism system hukum waris yang berlaku: Sistem Hukum Waris Barat, Sistem Hukum Waris Adat dan Sistem Hukum Waris Islam1.

Hukum Kewarisan yang bahkan berlaku sampai sekarang tersebut (baik hukum waris adat, hukum waris Islam maupun hukum waris Barat, merupakan hukum positif yang ditetapkan atau ditegakkan (enforcement) pengadilan. Menurut Mantan Ketua Mahkamah Agung, Bagir Manan, bermacam-macam hukum kewarisan tersebut walau tanpa kodifikasi, tanpa unifikasi, tidak berarti tidak aka nada hukum nasional. Keanekaragaman hukum, bukanlah sesuatu yang perlu dihindari, sepanjang tidak dimaksudkan untuk member privilege atau sebaliknya untuk merendahkan suatu kelompok. Keragaman hukum justru dapat bermanfaat dalam membangun kesatuan dan harmonisasi hubungan antar kelompok karena masing-masing merasa dihargai dan diberi tempat yang wajar dan masuk akal dalam tata kehidupan bersama, disamping itu juga dalam rangka mengakomodir landscape masyarakat Indonesia yang sangat pluralistic secara sosiologis.

Uraian tersebut menunjukan bahwa ada kaitannya antara hukum waris dan hibah warisan yang dikenal dalam sistem hukum Indonesia mengenai hibah penulis memulai dengan pengertian hibah yang di sebutkan dalam KUHPerdata. Menurut KUHPerdata Pasal 1666 menyatakan bahwa, hibah adalah suatu persetujuan dengan mana si penghibah diwaktu hidupnya dengan cuma-cuma dan dengan tidak dapat ditarik kembali, menyerahkan sesuatu benda guna keperluan si penerima hibah yang menerima penyerahan itu. Perluh ditegaskan disini bahwa penghibahan termasuk perjanjian sepihak, dimana hanya satu pihak saja yang mempunyai kewajiban atas perjanjian ini, yaitu si penghibah, sedangkan pihak yang menerima hibah sama sekali tidak mempunyai kewajiban.

Berdasarkan ketentuan tersebut, prinsipnya benda yang sudah dihibahkan tidak dapat ditarik kembali menjadi hak milik pemberi hibah. Akan tetapi, untuk kepentingan kewarisan, benda yang telah dihibahkan dapat "diperhitungkan kembali" nilainya ke 
dalam total harta peninggalan seolah-olah belum dihibahkan (Pasal 916a sampai Pasal 929 KUHPerdata). Ketentuan ini bermaksud agar jangan sampai hibah yang dahulu pernah diberikan oleh pewaris, mengurangi bagian mutlak yang seharusnya dimiliki oleh ahli waris yang disebut legitime portie.

Penghibahan untuk barang tidak bergerak seperti tanah dan bangunan yang dilakukan oleh para pihak dengan tidak menggunakan akta otentik maka keabsahan penghibahan itu tidak sah karena hibah harus dibuat dalam akta otentik, tidak bisa dibuat dalam akta di bawah tangan.

\section{Pertimbangan Hukum Putusan Perkara No. 175 K/PDT./2014}

Menyimak dasar putusan hakim adalah lebih mempertimbangkan aspek keapsahan suatu pemberian harta oleh pewaris kepada ahli waris. Dalam hal ini suatu pertimbangan bahwa ketika pewaris masih hidup dan memberikan harta benda kepada salah satu anaknya adalah sah dan bukan merupakan harta warisan. Menegani hibah telah diatur dalam KUHPerdata. Hibah harus memenuhi apa yang diatur dalam Pasal 1666 KUHPerdata bahwa hibah merupakan pemberian oleh seseorang kepada orang lainnya secara cuma-cumadan tidak dapat ditarik kembali, atas barang-barang bergerak (dengan akta Notaris) maupun barang tidak bergerak (dengan akta Pejabat Pembuat Akta Tanah - "PPAT") pada saat pemberi hibah masih hidup. Artinya bahwa hibah merupakan kehendak bebas si pemilik harta untuk menghibahkan kepada siapa saja yang ia kehendaki. Jadi, pemberi hibah bertindak secara aktif menyerahkan kepemilikan hartanya kepada penerima hibah.

Bahwa perluh ditegaskan disini adalah kebebasan selalu dibatasi dengan hak pihak lain. Di dalam harta pemberi hibah, terdapat hak bagian mutlak (legitieme portie) anak sebagai ahli warisnya dan hak ini dilindungi undang-undang. Sehingga untuk mencegah terjadinya tuntutan di kemudian hari, dalam praktik selalu disyaratkan adalah Surat Persetujuan dari anak-anak kandung pemberi hibah. Dengan demikian, pemberian hibah harus memperhatikan persetujuan dari para ahli waris dan jangan melanggar hak mutlak para ahli waris yang lain sebagaimana diisyaratkan undangundang. Hak mutlak adalah bagian warisan yang telah di tetapkan oleh undangundang untuk masing-masing ahli waris (bdk Pasal 913 KUHPerdata). Hal tersebut menegaskan bahwa kesamaan yang diutamakan. Kesamaan inilah yang menurut Aristoteles menekankan pada keadilan komutatif. Menurut Aristoteles keadilan komutatif memberi kepada setiap orang sama banyaknya. Dalam pergaulan di dalam masyarakat, 
Laike, Reli Jevon. \& Laike, David. Problematika Hiba Warisan Ditinjau Dari Aspek Keadilan Studi Di Pengadilan Negeri Tobelo

keadilan komutatif merupakan kewajiban setiap orang terhadap sesamanya. Di sini yang dituntut adalah kesamaan. Yang adil ialah apabila setiap orang diperlakukan sama tanpa memandang kedudukan dan sebagainya. Hal inilah yang kemudian putusan hakim tidak mempertimbangkan aspek keadilan, diamana parah ahli waris harusnya mendapatkan biagian yang sama dalam pembagian warisan baik itu melalui hibah dan lain-lain.

Perluh penulis tegaskan disini bahwa dalam permasalahan ini melibatakan pihak yang tunduk pada KUHPerdata (non muslim). Sehingga akan tunduk pada aturan yang ada di Pasal 881 ayat (2) KUHPerdata, yang mengatakan bahwa "dengan sesuatu pengangkatan waris atau hibah yang demikian, si yang mewariskan tak boleh merugikan para ahli warisnya yang berhak atas sesuatu bagian mutlak".

Berdasarkan hal tersebut hakim harusnya mempertimbangkan keadilan menurut hukum maupun keadilan menurut lingkungan masyarakat. Penulis sependapat dengan seorang tokoh yang bernama F. Geny bahwa seorang hakim harus pertama-tama mengindahkan undang-undang dengan memperhatikan maksud dan tujuan pembentuk undang-undang dan logika intern dan sistematik undang-undang. Logika tersebut menyangkut asas putusan pengadilan harus memuat alasan dan dasar yang jelas. Maksud dari asas tersebut adalah Putusan pengadilan yang dijatuhkan harus memuat alasan dan dasar pertimbangan yang cukup. Putusan yang tidak memenuhi ketentuan tersebut dikategorikan putusan yang tidak cukup pertimbangan. Alasan-alasan hukum yang menjadi dasar pertimbangan bertitik tolak dari ketentuan : pasal-pasal tertentu peraturan perundang-undangan, hukum kebiasaan. Hal tersebut ditegaskan dalam Pasal 50 ayat (1) Undang-Undang Nomor 482009 bahwa Putusan pengadilan selain harus memuat alasan dan dasar putusan, juga memuat pasal tertentu dari peraturan perundang-undangan yang bersangkutan atau sumber hukum tak tertulis yang dijadikan dasar untuk mengadili.

Senada dengan hal tersebut Mertokusumo, berpendapat bahwa hakim pada dasarnya tidak boleh melanggar undang-undang, tidak boleh melanggar sistem, harus berfikir system orient. Selanjutnya bahwa hakim dalam mengambil sebuah putusan diberi tugas untuk menemukan hukum. Penemuan hukum Menurut Sudikno Mertokusumo hakim lazimnya diartikan sebagai proses pembentukan hukum oleh hakim untuk melaksanakan hukum atau menerapkan peraturan hukum umum terhadap peristiwa hukum yang konkret. Hal tersebut dimana hakim kasasi harusnya mengindahkan undang-undang yang terkait dengan perkara tersebut. 
Berdasarkan hal tersebut menurut Sumartoyo, profesi hakim merupakan jabatan pengadil, yang memiliki tanggung jawab untuk tidak saja menerima, memeriksa, dan memutuskan perkara yang diajukan di pengadilan berdasarkan selera hakim, melainkan harus mampu menghadirkan kepastian hukum dan rasa keadilan atau ketertiban yang berkeadilan. Apabila hukumnya tidak jelas, tidak lengkap, atau bahkan tidak ada, maka hakim harus mencari hukumnya atau melakukan penemuan hukum. Sehubungan dengan hal tersebut bahwa menyangkut putusan hakim adalah merupakan dari kepentingan masyarakat dan negara yang sangat mendasar, maka dorongan dan simpati publik akan selalu memainkan peran dalam menilai sebuah putusan hakim. Hal ini secara asasi telah ditegaskan dalam pembukaan Undang-Undang Dasar Negara Republik Indonesia Tahun 1945 bahwa negara Indonesia berdasarkan atas hukum yang artinya adalah negara hukum, maka salah satu unsur fundamental dari negara hukum adalah penegakan hukum oleh lembaga peradilan dalam hal ini melalui putusan hakim yang seyogiayan mencermikan asas tersebut, di mana hakim tidak bertindak atas kehendak pribadi tetapi hakimterikat pada peraturan terkait perkara yang sedang di hadapi, hal ini adalah representasi dari konstutisionalisme.

Putusan hakim itu di anggap adil bila aspek keadilan itu sudah dirumuskan dalam suatu kepastian hukum, artinya bahwa keadilan itu terwujud apa bila hak-hak masyarakat yang telah diatur dalam suatu aturan itu diwujudkan. Sebabnya menurut Theo Huijbers, bahwa hukum bermaksud menciptakan suatu aturan yang adil, berdasarkan hak-hak manusia yang sejati. Manurut Aristoteles menyatakan bahwa ukuran keadilan adalah bahwa : 1, Seseorang tidak melanggar hukum yang berlaku, sehingga keadilan berarti "lawful", yaitu hukum tidak boleh dilanggar dan aturan hukum harus diikuti; dan 2. Seseorang tidak boleh mengambil lebih dari haknya, sehingga keadilan berarti persamaan hak (equal). Adil dapat berarti menurut hukum, dan apa yang sebanding, yaitu yang semestinya. Hal tersebut dihubungkan dengan peran seorang hakim dalam mengambil keputusan harus menilai pertama-tama keadilan yang dimaksudkan pembentuk undang-undang, dan pertimbangan keadilan tidak bisa melampaui apa yang menjadi hak-hak para pihak. Sejalan dengan hal tersebut Hans Kellsen memandang keadilan, yaitu keadilan yang lahir dari hukum positif yang ditetapkan oleh manusia berdasarkan norma dasar berlakunya hukum positif. Sehingga dilihat dari putusan hakim kasasi dalam perkara tersebut, para pihak terlebih khusus, pihak termohon tidak terdapat ukuran keadilan, menurut Mochtar Kusumaatmadja dan 
Laike, Reli Jevon. \& Laike, David. Problematika Hiba Warisan Ditinjau Dari Aspek Keadilan Studi Di Pengadilan Negeri Tobelo

B. Arief Sidharta, mengatakan keadilan merupakan unsur yang tidak bisa dipisahkan dari hukum sebagai perangkat asas dan kaidah yang menjamin adanya keteraturan (kepastian).

Rasa keadilan masyarakat, bagi Aristoteles berarti hakim harus mempertimbangkan hukum yang hidup dalam masyarakat, yang terdiri atas kebiasaan hukum yang tidak tertulis. Dalam hal ini harus dibedakan keadilan menurut individu, kelompok, dan masyarakat. Selain itu keadilan dari suatu masyarakat tertentu, belum tentu sama rasa keadilan dengan masyarakat lain. Jadi dalam pertimbangan putusannya, hakim harus mampu menggambarkan hal tersebut, manakalah hakim memilih asas keadilan sebagai dasar menjatuhkan putusan. Maka untuk bertindak secara adil, kata Aristoteles, seorang hakim harus menyelami sungguh-sungguh perkara-perkara yang konkret, seolah-olah hakimlah sebagai saksi mata sendiri. Hal ini menunjukan bahwa penalaran seorang hakim sangat dibutuhkan.

Sehubungan dengan hal-hal tersebut yang suda diuraikan menunjukan bahwa hakim tidak bersifat bebas dan tanpa batas dalam menjatuhkan putusan, sehingga dalam mengambil keputusan sedapat mungkin merupakan resultante dari ketiganya. Artinya hukum kehilangan artinya bilah kekuasaan itu melampaui apa yang menjadi kehendak undang-undang. Pandangan tersebut menurut Theo Huijbers, mengatakan bahwa hukum bermaksud menciptakan suatu aturan masyarakat yang adil, berdasarkan hak-hak manusia yang sejati. Hak-hak manusia yang sejati ini telah termuat dalam Pasal 28I ayat (5) Undang-Undang Dasar Negara Republik Indonesia Tahun 1945 yang menetapkan bahwa "Untuk menegakkan dan melindungi hak asasi manusia sesuai dengan prinsip negara hukum yang demokratis, maka pelaksanaan hak asasi manusia dijamin, diatur, dan dituangkan dalam peraturan perundang-undangan". Tujuan ini hanya tercapai kalau pemerintah tinggal di bawah norma-norma keadilan, dan mewujudkan suatu aturan yang adil melalui undang-undang. Berarti hukum letahnya di atas pemerintah. Pemerintah harus bertindak sebagai abdi hukum.

Menurut hemat penulis bahwa putusan pengadilan juga wujud dari bagaimana menghormati hak-hak asasi manusia, melindungi, dan menegakan, oleh karenanya hakim tidak bersifat bebas tanpa batas, tetapi kebebasan hakim berada dalam lingkungan hukum. Sebagai penegasan penulis berdasarkan Yurisprudensi Mahkamah Agung Republik Indonesia Nomor : 990/K/Sip/1974 tanggal 6 April 1976, bahwa hibah wasiat 
tidak boleh merugikan ahli waris dalam hal ada ahli waris yang dirugikan oleh adanya hibah wasiat itu, hibah tersebut harus dibatalkan.

\section{SIMPULAN}

Merujuk pada hasil pembahasan yang telah diuraikan pada bab-bab sebelumnya, maka dibagian penutup ini penulis dapat mengambil kesimpulan yakni, dalam perkara ini seyogyanya hakim tidak terikat pada undang-undang saja dalam hal ini pertimbangan sahnya suatu pemberian hibah warisan oleh pewaris kepada ahli warisnya. Tetapi hakim dalam mengambil keputusan harus memperhatikan aspek yang lain seperti nilai keadilan yang hidup dalam masyarakat menyangkut perimbangan pembagian harta warisan kepada seluruh ahli warisnya. Sehingga tidak terkesan dalam masyarakat tidak adanya pilih kasih oleh pewaris kepada alih warisnya. Oleh karenanya hakim harus benar-benar menyelami setiap persoalan yang dialami para pihak, dalam artian seolah-olah hakimlah yang menjadi saksi bagi para pihak yang berperkara.

\section{UCAPAN TERIMAKASIH (Optional)}

Dalam pelaksanaan penulisan ini tentunya tidak luput dari bantuan yang telah diberikan baik secara materi maupun dalam bentuk ide dan gagasan. Ucapan terimakasih petama kepada penulis kedua yang mana kerjasama dan kekompakan dalam melakukan penelitian dan penulisan ini mulai dari penyiapan dana, penyiapa data, saling diskusi hingga penyusunan rumusan naskah ini selesai tentunta adalah kerjasama yang baik. Juga berbagai pihak yang telah membantu memberikan data khususnya pengadilan. Dibalik semua itu juga kami sebagai penulis menyadari bahwa hikmat tanpa kuasa Tuhan adalah sia-sia, sehingga dalam kesempatan ini kami mengucap syukur kepada yang Tuhan atas segala hikmat dan berkatnya sehingga penulisan ini bisa berjalan dengan lancar. Amin.

\section{DAFTAR PUSTAKA}

Ahmad Rifai, (2010). Penemuan Hukum Oleh Hakim Dalam Perspektif Hukum Progresif, pertama, Jakarta: Sinar Grafika.

Bagir Manan (2009), Menuju Hukum Waris Nasional,yang disampaikan dalam Simposium tentang Menuju Surat Keterangan Waris Yang Bersifat Nasional bagi WNI, yang di selenggarakan pada tgl 6 Mei 2009 oleh BPHN bekerjasama dengan Ikatan Keluarga Alumni Notariat-UNPAD di Jakarta

Hyronimus Rhiti, (2011). Filsafat Hukum edisi lengkap Idari Klasik sampai postamodernisme), pertama, Yogyakarta: Cahaya Atma Pustaka.

Maskun dkk, (2013). Filsafat Hukum Teori Dan Praktik, Kesatu, Jakarta: PT Kencana Perdana Media Grup 
Laike, Reli Jevon. \& Laike, David. Problematika Hiba Warisan Ditinjau Dari Aspek Keadilan Studi Di Pengadilan Negeri Tobelo

Mochtar Kusumaatmadja dan B. Arief Sidharta (2000). Pengantar Ilmu Hukum, Suatu Pengenalan Pertama Ruang Lingkup Berlakunya Ilmu Hukum, Bandung: Alumni.

Mertokusumo, (2012). Teori Hukum, kedua, Yogyakarta: Cahaya Atma Pustaka.

Munir Fuady, Fuady Munir. (2010). Dinamika Teori Hukum, Kedua, Bogor: Ghalia Indonesia.

Sudikno Mertokusumo, (2012), Teori Hukum, Yogyakarta: Cahaya Atma Pustaka.

Sudikno Mertokusumo, (2015). Mengenal Hukum Suatu Pengantar, keempat, Yogyakarta: Chaya Atma Pustaka.

Shidarta dkk. (1995). Pokok-Pokok Filsafat Hukum (Apa Dan Bagaimana Filsafat Hukum Indonesia), Kedua. Jakarta: Gramedia Pustaka.

Samosir Djamanat. (2011). Hukum Acara Perdata Tahap-Tahap Penyelesaian Perkara Perdata, Pertama, Bandung: Nuansa Aulia.

Theo Huijbers, . (1990). Filsafat Hukum, Pertama, Yogyakarta: Kanisius.

Theo Huijbers. (2015). Filsafat Hukum, Ketujubelas, Yogyakarta : Kanisius.

BPHN, (2009). Simposium tentang Menuju Surat Keterangan Waris Yang Bersifat Nasional bagi WNI, yang di selenggarakan pada tgl 6 Mei 2009 oleh BPHN bekerjasama dengan Ikatan Keluarga Alumni Notariat-UNPAD di Jakarta.

Kitab Undang-Undang Hukum Perdata 